\title{
Zeki Demirkubuz Filmlerindeki Kadın Temsillerinin Feminist Film Eleştirisi Çerçevesinde İncelenmesi: C Blok, Masumiyet, Üçüncü Sayfa
}

\author{
Müge Karabağ (Doktora Öğrencisi) \\ İstanbul Üniversitesi Sosyal Bilimler Enstitüsü \\ mugekarabag88@gmail.com \\ Orcid: 0000-0002-8141-3557
}

Başvuru Tarihi: 11.03.2019

Yayına Kabul Tarihi: 02.05.2019

Yayınlanma Tarihi: 22.07.2019

DOI: $10.17680 /$ erciyesiletisim.538328

Karabağ, M. (2019). Zeki Demirkubuz Filmlerindeki Kadın Temsillerinin Feminist Film Eleștirisi Çerçevesinde İncelenmesi: C Blok, Masumiyet, Üçüncü Sayfa. Erciyes İletişim Dergisi, 6 (2), 1427-1444. DOI: 10.17680/erciyesiletisim.538328

\section{Öz}

Bu çalışmada 90'lı yıllarda ana karakterin kadın üzerine yoğunlaştığı ZekiDemirkubuz'un üç filmini feminist film teorisi üzerinden incelemek ve bu anlamda literatüre katkı sağlamak amaçlanmıştır. İncelenen filmler C Blok, Masumiyet ve Üçüncü Sayfa filmleridir. $\mathrm{Bu}$ filmlerin feminist film teorisi bağlamında analiz edilmesinin sebebi, bu teorinin toplumun kodladığı ataerkil kalıpların sinemaya uyarlanış biçimlerini ve filmlerde sergilenen toplumsal cinsiyet algılarının tasvirlerini tartıșmasıdır. Makalede söz konusu filmlerdeki ana ve yan kadın karakterlerin var olma mücadelelerinin, amaçlarının ve kendilerini ifade etme biçimlerinin temelde aynı doğrultuda olup olmadığı gibi değişkenler tartışılmıștır. Her üç filmdeki kadın karakterlerin, toplumda hangi statüyle yer aldıkları, sosyo-kültürel konumları, erkeklerle olan ilişkileri değerlendirilerek söz konusu filmlerde cinsiyetçi yaklaşımların ve kadın rollerinin nasıl betimlendiği metin analizi yöntemiyle incelenmiştir. Çalışmada söz konusu filmler analiz edilmeden önce feminist film teorisi kuramsal açıdan değerlendirilmiştir. Daha sonra söz konusu filmlerin çekildiği 1990'lı yıllardaki Türk filmlerinde kadın temsilinin değişimi ve bu değişimin kökleri irdelenmiştir. Ardından Zeki Demirkubuz sinemasındaki kadın ve erkek temsillerinin farklılıklarına ve yönetmenin diğer filmlerindeki kadın karakterlere kısa bir şekilde değinilmiştir. Akabinde makalede kullanılacak yöntem olan metin analizi modeli açılklanarak, üç film de bu yönteme göre çözümlenmeye çalışılmıştır. Buna göre belirlenen üç filmde kadınların, feminist film teorisyenlerinin karşı çıktığı kadın temsillerine uyduğu ve bu filmlerdeki kadınların sadece cinsel bir nesne konumunda tasvir edildiği görülmüştür. Yapılan analizlere göre üç filmdeki kadın karakterlerin cinsellik ve ihanet noktasında birleștiği ve bu karakterlerin erkek bakışının bir uzantısı olarak eril nazar etkisinde temsil edildiği belirlenmiștir.

Anahtar Kelimeler: Feminist Sinema, Zeki Demirkubuz, Türk Sineması, Kadın, Metin Analizi. 
Research Article

\title{
Analysis of Female Representations in Zeki Demirkubuz Films by Feminist Film Criticism: C Block, Innocence, Third Page
}

\author{
Müge Karabağ (Ph.D. Student) \\ İstanbul University Institute of Social Sciences \\ mugekarabag88@gmail.com \\ Orcid: 0000-0002-8141-3557
}

Date Received: 11.03.2019

Date Accepted: 02.05.2019

Date Published: 22.07.2019

DOI: 10.17680/erciyesiletisim.538328

\begin{abstract}
With this study, it was aimed to examine three films of Zeki Demirkubuz through the feminist theory of film in which the main character had become women in the 90's and in this sense to contribute to the literature in general. The films are analysed C Block, Innocence and Third Page respectively. The reason why these films are analysed in the context of feminist film theory is that this theory discusses how the patriarchal patterns which are encoded by the society are adapted to the movies and the analysis of the description of the perception of the gender roles in society. In the article it is discussed whether the variables such as the main and subordinate women characters styles of expressing themselves, their aims, their fights of survival are basically in line with each other or not. In the article the role of female characters, whatever status they have in the society, their social-cultural positions, their relationships with men evaluated bearing in mind the gender approaches and the descriptions of female roles in the relevant movies, through using the method of text analysis. In this study feminist film theory evaluated in terms of theoretical view point before the analysis of the above-mentioned films. In accordance with the above intentions, the text analysis model which have been used in the article explained in order to analyse the three films in question. In conclusion it would be seen that the women identified in these 3 movies fit in the stereotypical representations of women which the film theoreticians are against, unfortunately they are only portrayed as sexual objects. According to the analysis, it was determined that the female characters in the three films converged at the point of sexuality and betrayal, and these characters were represented under the masculine perspective as an extension of the male gaze.
\end{abstract}

Keywords: Feminist Cinema, Zeki Demirkubuz, Turkish Cinema, Woman, Text Analysis. 


\section{Giriş}

Sinema, insanın dünya ile ilişkisinden ve toplumların sosyo-kültürel yapısından beslenmektedir. Dolayısıyla sinema filmlerinin var olan toplumsal ve kültürel yapının temellendirdiği hâkim düşüncelerle oluşturulduğunu söylemek mümkündür. Sinemada filmlerin ana unsuru olan kadın ve erkek özneleri, toplumların o öznelere atfettiği anlamlarla temsil edilmektedir. Diğer kitle iletişim araçlarında olduğu gibi sinemada da sergilenen temsillerin, yönetmenin ideolojik bakış açısından etkilendiği ve bu temsillerin sinemayı diğer kitle iletișim araçlarından ayıran sanat ve estetik gibi kavramlar vasıtasıyla şekillendirildiği düşünülmektedir. Bu şekilde kadın ve erkek öznelerinin toplumdaki yaygın görüşleri etkileyerek onların oluşmasına öncülük ettiği tartışılmaktadır. Dolayısıyla filmlerin temsili öğeler yoluyla birtakım tezleri ileri sürerek, izleyiciye belli bir bakıș açısını da telkin ettiğini belirtmek mümkündür (Ryan ve Keller, 2010, 18). Bu açıdan erkek egemen toplumlarda da sinemadaki kadın temsillerinin erkek bakışının bir uzantısı olduğunu ifade etmek yanlış olmayacaktır. Kadın erkek ilişkileri, kadın ve erkeğe yönelik kalıplaşmış bakış açıları topluma içkindir ve bu doğrultuda sinemada da bunun temsilleri görülmektedir. Türk sinemasındaki kadın temsillerinin de toplumda kadına yönelik kabul görmüş stereotipler temelinde şekillendiği düşüncesi yaygın bir görüştür. Kadının toplumsal hayattaki varoluş mücadelesinin beyaz perdeye de yansıdığı, senaryolardaki kadın karakterlerin erkek bakışının bir ürünü olarak ortaya çıktığı düşünülmektedir. Bu anlayış çerçevesinde oluşan feminist film eleştirisi, filmlerde kadınların salt bir kadın olarak var olmadıklarını, erkek bilincinin bir tasviri olarak temsil edildiklerini kabul etmektedir (Özden, 2004, 194).

Türk sinemasında kadın temsillerinin incelenmesine yönelik pek çok çalışma yapılmıştır. Bu çalışmalardan bazılarını belirtmek gerekirse; Fetay Soykan’ın “Türk Sinemasında Kadın” başlıklı doktora tezi ile Nursel Güler'in Zeki Demirkubuz filmlerindeki kadın temsillerini psikanalitik film çözümlemesiyle ele aldığı "Zeki Demirkubuz Sinemasında Kadın Temsilleri” adlı yüksek lisans tez çalışması, beyaz perdedeki kadın temsillerinin değerlendirilmesine yönelik önemli katkılar sunmaktadır. Bu çalışma ile 90'lı yıllarda ana karakterin kadın üzerine yoğunlaştığı, Zeki Demirkubuz'un üç filmini feminist film teorisi üzerinden incelemek ve bu anlamda literatüre katkı sağlamak amaçlanmıştır. Metin analizi yöntemiyle incelenecek filmler C Blok, Masumiyet ve Üçüncü Sayfa filmleriyle sınırlandırılmıștır. Çalışmanın kapsamına giren bu üç filmdeki kadınların ortak noktaları, hikâyelerinin cinsellik ve ihanet noktasında birleşmesidir.

Metin analizi yöntemi ise medya çalışmalarında sıklıkla kullanılan bir yöntemdir ve bu yönteme göre filmler, televizyon programları veya televizyon dizileri, haber içerikleri, radyo programları gibi medya içerikleri bir metin olarak ele alınmaktadır. Ancak burada önemli olan metni çevreleyen bağlamlardır. Dolayısıyla metin olarak kabul edilen içerik yani metin, onu çevreleyen diş gerçekliğin oluşturduğu "toplumsalkültürel-siyasal" çerçeve örgüsü içerisinde ele alınmalı ve çözümlenmelidir (İnceoğlu ve Çomak, 2009, 19).

Makalenin kapsamına giren filmlerdeki kadınlar, onları çevreleyen diş gerçekliklerle, toplumsal, kültürel ve sosyal açıdan analiz edilmiștir. Ayrıca metin analizi yöntemiyle ilgili detaylı bilgi makalenin yöntem bölümünde verilmiştir. 
Seçilen filmlerdeki kadın temsillerinin, feminist film eleştirisinin kapsamına girdiği ve söz konusu kadın temsillerinin eril nazar çerçevesinde oluşturulduğu çalışmanın hipotezidir.

Seçilen filmlerin feminist film teorisi bağlamında analiz edilecek olmasının sebebi, bu teorinin toplumun kodladığı ataerkil kalıpların sinemaya uyarlanış biçimlerini ve filmlerde sergilenen toplumsal cinsiyet algılarının tasvirlerini tartışmasıdır. Dolayısıyla bu makale, sinemamızdaki klişe kadın temsillerinden farklı bir düzlemde ana karakterlere rol biçilen üç filmi, feminist film teorisiyle incelemesi bakımından önem taşımaktadır.

\section{Kadının Sinemada Varoluş Mücadelesi: Feminist Film Teorisi}

Feminist kuramcılar, sinemada kadın temsillerinin erkek bakışının bir uzantısı olduğu konusuna yoğunlaşmışlar ve kadının beyaz perdedeki bu temsillerine yönelik eleştirilerde bulunmuşlardır. Bu anlamda özellikle 1960'lı yıllardan itibaren feminist kuramlar sinema alanında da etkin olmuş ve patriyarkal sistemin sinemadaki temsilleri üzerinde de söz sahibi olmaya başlamıștır. Feminist teori, kadın kimliğinin ikincil toplumsal konumunu ortaya koyarak buna karşı kadınların bilincini yükseltmeyi amaçlayan bir kuramdır. 1960'lı yıllarda hız kazanan feminist teori dahilinde, kadın kimliğinin erkeğinkiyle eşitlenmesi amacıyla birçok çalışma yapılmıştır. (Donovan, 1997, 23).

Kadın hareketinin yükselişe geçmesiyle bağımsız sinemada da feminist hareketin yansımaları görülmeye başlanmıştır. Bu kapsamda ortaya çıkan ve ilerleyen süreçte geliştirilen feminist film kuramı, kadının beyaz perdedeki temsillerine, eril bakıș açısıyla çekilen filmlerdeki kadın karakterlerin sinemada "ikinci sınıf" veya "zayıf" karakterli sıfatlarla temsil edilmesine karşı duran bir söylemler bütününden oluşan bir kuramdır. Sinemadaki cinsiyetçi söylemlere ve imgelere karşı bir eleştiri unsuru olan feminist kuramlar toplumsal, politik ve psikanalitik teorilerle ortak cinsiyet eşitsizliğine eğilirler. Feminist film teorisi ataerkil sinemaya ve filmlerde kullanılan eril dile karşı durmaktadır. (Arslantepe, 2010, 4).

Kadın, feminizmin öznesi olarak kabul edilmektedir. Kadının denetim mekanizmaları ve egemen güçler tarafından ötekileștirilmesi ve kadının toplumsal hayatta yaşadığı sorunlar gibi konular ise feminizmin ele aldığı problemlerdir (Butler, 2008, 43). Bu açıdan feminizm, genellikle toplum tarafından kadına yüklenen "eksiksiz kadınlık" rolünün sorgulanması ve modern düşüncelerin oluşturduğu bireysel bağımsızlık, özgürlük ve kendini keşfetme ruhu içinde toplumda genel kabul gören kadın statüsünün güvencelerini eleştirme ve sorgulama anlamına gelir (Durakbaşa, 2002, 53). Feminizm işte bu noktada toplumsal hayatın her alanında etkin olan cinsiyet hiyerarşisini sonlandırmak ve kadın ile erkeğin eşit koşullarda var olmasını sağlamayı amaçlamaktadır. İçeriğini toplumdan alan edebiyat ve sinema gibi sanat dallarında da bu cinsiyet hiyerarşisi görülmektedir. Bu sebeple sinemadaki kadın temsillerinin incelenmesine yönelik yapılan çalışmalar feminist film teorisi üzerinden aktarılmaktadır. Sinemanın özneleri, kadınlar ve dişilik ile erkekler ve erilliktir. Yani sinema, cinsel farklılıklar üzerine mitlerin tekrar edilerek üretildiği ve bunların temsil edildiği kültürel bir pratik olarak tanımlanmaktadır (Smelik, 2008, 1). Bu açıdan feminist film eleştirisi, erkek egemen sinemanın kadınlar üzerinde oluşturdukları yapay stereotiplere, beyaz perdede kadın temsillerinin çeşitli imgelerle adeta erkek bilincinin bir dışavurumu şeklinde gösterilmesine karşı 
çıkmaktadır. Feminist eleştirmenler beyaz perdedeki kadın temsillerinin gerçekliği yansıtmadığını, kadın karakterlerin, iç dünyalarından fiziksel görünümlerine kadar eril düşünce ve dilin tasviriyle oluşturulduğunu ifade etmektedirler. Zira gerçeklik, sinemada da "gerçekten" olduğu gibi gösterilirse ideoloji ve toplum değişir. Böylece sinemada kadın bir yönetmenin elinden çıkan bir filmde kadın karakterler, gerçekliği yansıtacak ve erkeklerin fantezi dünyalarındaki yapay kadın tiplemelerinin yarattığı kısır döngülerden kurtulacaktır (Smelik, 2008, 3).

Feminist film teorisyenlerine göre kadın sinemada yoktur. Sadece erkeğin bilinçaltı ve arzularının yarattığı kadın tiplemeleri vardır (Özden, 2004, 194). Feminist eleştirmenlere göre nasıl ki toplumsal hayatta kadın yoktur, bu durum sanata da yansımaktadır. Kadının toplumsal hayatta var olamamasına ve eril hegemonyanın sadece ona biçtiği rolleri yerine getirmesine yönelik yapılan eleştiriler bu çerçevede gerçekleşmektedir. Kadın, toplumda erkeklerin kendisine yakıştırdığı maskeyi ödünç alır ve rolüne bürünür. Kadından beklenen şey sadece dişiliğiyle var olması ve bu sahteliği, yapaylığı sürdürmesi ve yaymasıdır. (İrigaray, 2001, 10). Tıpkı ilk dönem Hollywood filmlerinde kadının bir süs bebeği yahut bir seks objesi olarak sunulması gibi... Bu sebeple feminist film teorisyenlerine göre, bir Marleine Dietrich'in, Marilyn Monreo'nun ya da Greta Garbo'nun cazibesine karşı kadın yönetmenler "normal" yani cazibesiz kadının gündelik hayatını filme çekmelidirler (Smelik, 2008, 3). Bu cazibeli yıldızların ve genel olarak tüm kadınların sinemadaki rolleri 1960’lı yıllarda sorgulanmaya başlanmıștır. Hollywood sinemasının klasik kadın temsillerine yapılan geniş çaplı eleştiriler ve sorgulamalar feminist film teorisinin ortaya çıkmasını sağlamıştır. 1970'li yıllarda üniversitelere film bölümlerinin de açılmasıyla film kuramı akademik alanda da önem kazanmıştır. Tüm bunlar feminist film kuramı ve eleştirisinin hızla gelişmesini sağlamıştır (Özden, 2004, 195). Feminist sinema kuramının öncüleri Claire Johnston ve Laure Mulvey, kadının cinsel bir obje olarak beyaz perdedeki sunumunun erkek egemenliğiyle olan ilişkisini ele almışlardır. Claire Johnston, Woman's Cinema as Counter-Cinema adlı makalesinde kadının tek tipleștirildiğini ve kadının erkek bakışının uzantısı olduğunu öne sürmüştür (Arslantepe, 2010, 4). Bu açıdan Claire Johnston, sinemayı semiyotik bir gösterge sistemi olarak inceleyen ilk feminist film eleştirmenlerindendir. Johnston'a göre beyaz perdedeki kadın göstergesi, sadece erkekler için taşıdığı ideolojik anlamı temsil etmektedir, özgün ve bağımsız bir halde var olamamaktadır ve bireysel olarak hiçbir anlam ifade etmemektedir. Johnston, sinemada kadını "gösterge" olarak tanımlamaktadır ve feminist sinemayı gösterge bilimsel bir yöntemle incelemektedir (İnceoğlu, 2015, 88). Başka bir ifadeyle, kadın karakterinin sinemadaki tek işlevi "gösteren" olmaktır. Bu şekilde kodlanan kadın, erkeğin ideolojik önemini ve anlamını temsil etmektedir. Kadın ancak erkeklerle ilişki içindeyken bir göstergedir; tek başına bir hiçtir ve bir şey ifade etmemektedir (Uluç ve diğerleri, 2006, 6).

Laura Mulvey ise sinemadaki ataerkil yapıyı Freud temelli psikanalitik bir teoriyle yorumlamaktadır. Mulvey'nin geliștirdiği eril nazar teorisi, feminist film teorisi kapsamında en sık bahsedilen konulardan biri haline gelmiştir. Mulvey, sinemada kullanılan öykü ve kadın imgelerinin bakma arzumuzu kıșkırttığını ve bunun dikizcilik ve narsizm temelinde gerçekleştiğini belirtir. Bakmaktan alınan haz, cinsiyet farkı ekseninde ve etken edilgen bir yapıdadır. Klasik sinemada erkek etken, kadın ise edilgen yapıdadır. Erkek iktidar sahibidir ve dramatik aksiyon, erkek aktörün çevresinde açılır ve bakış bu yolla örgütlenir. (Smelik, 2008, 4-5). Başka bir 
deyişle Mulvey, sinemanın kadın ve kadına özgü metaforlara bakma arzusu sebebiyle izleyicilere zevk verdiğini ifade etmektedir. Bununla birlikte Mulvey, erkeğin zevkinin sinemadaki görsel zevk üzerinde kontrol sahibi olduğunu ve feminist film eleştirisiyle ataerkil düzenin oluşturduğu arketip ve stereotiplere hizmet etme görevinin reddedilmesi gerektiğini belirtmektedir (Özden, 2004, 204). Smelik'e göre eril bakış, sinemada dikizcilik ya da fetişizm gibi kavramlarla şekillenen karmaşık mekanizmaları çözümlemek için kullanılan kestirme bir terim haline gelmiştir. Bu kavramlar, patriyarkal yani erkek egemen düzen ekseninde Hollywood sinemasının nasıl oluştuğuna ilişkin yapılan çalışmalarda kullanılmaktadır (Smelik, 2008,6). Erken dönem feminist kuramcllar Claire Johnston ve Laura Mulvey aslında paralel bir bakış açısıyla eleştirdikleri patriyarkal sinemaya karşı bir sinema olması gerektiğini ve bu karşı sinemada klasik tekniklerin kullanılmadığı, deneysel pratiklere yer verilmesi gerektiği üzerinde durmuşlardır (Smelik, 2008, 7). Feminist film teorisyenlerine göre sinemada kadın ve erkekler belirli kalıplarla izleyiciye sunulmakta ve o kalıpların dışına çıkan karakterler "kötü" olarak temsil edilmektedir. Erkekler güçlü, evine bağlı, güvenilir bir eş ya da sevgili olarak, kandırılmayan karakterlerde ve her zor koşulda kurtarıcı görevindedirler. Kadınlar ise mükemmel bir anne veya eştirler, her koşulda eşlerinin ya da sevgililerinin yanındadırlar. Bu ideal karakterlerin yanında bir de yan karakterler vardır. Bunlardan biri de erotik kadın imgesidir. Bu tip kadınlar maceracı, kumar oynayan ve tehlikeli kadınlardır (Öztürk, 2000a, 72).

\section{0'Iı Yıllarda Türk Sinemasında Kadın Temsili}

Türk sinemasında kadının temsili ile Türk filmlerindeki cinsiyetçi konular ve söylemler, sosyal bilimler alanında sıkça işlenen konulardan olmuştur. Zira sinemamızdaki kadın temsillerinin uzun yıllar hep aynı noktada kaldığı ve klişelerin ötesine geçemediği düşünülmektedir. Buna göre senaryolar daima kadın mağduriyeti ve kadının sebep olduğu öne sürülen dramlar üzerine yoğunlaşmıştır. Yeşilçam filmlerinde işlenen kadın imgeleri 1980'li yıllara kadar, iyi ve kötü kadın karakterleriyle sınırlandırılmış ve sınıflandırılmıştır. Kadınlar namuslu, evinin kadını çocuklarının anası, kendine ait cinsel tercihleri olmayan, sevgi ve şefkat dolu, anaç, üzülüp acı çekse de bunu belli etmeyen kadınlardır. Ya da bu kadınlar cinselliğini kullanan, kötü, yuva yıkan ve erkekleri kötü yollara sürükleyen vamp kadınlar olarak işlenmiştir (Esen, 1996, 12). 80'li yıllardan sonra ise beyaz perdedeki kadın hikâyeleri yavaş yavaş bireyselleşmeye, kadın sorunlarının anlatılmasına dönüşmeye başlamıştır. Türk sinemasında bu dönem itibariyle kadın sorunlarına değinen, klişe kadın rollerinden ziyade özgür iradesini kullanan, bireysel kadınlar beyaz perdede temsil edilmeye başlanmıştır. Yeşilçam'ın klasik anlamda "namuslu", "itaatkâr" ve "fedakâr" kadın rollerinden sıyrılıp, feminist hareketin arzuladığı şekilde, kadını tek tipleștirmeden yazılan kadın hikâyeleri boy göstermiştir. Filmlerdeki kadın temsillerinin 80'lerden sonra değişim göstermesi, kadın hareketlerinin bu dönemde gelişmesine bağlanmaktadır. Kadınların kolektif bir tutumla cinsiyet ayrımcılığına karşı mücadele etmesi, sinemadaki kadın temsillerine de yansımıștır (Yücel, 2011, 45). Bu dönemde kadın sorunlarına değinen ve kadının sosyal hayatta bireysel olarak var olma mücadelesini anlatan filmler çeken Atıf Yılmaz, sinemamızdaki klişe kadın tiplemelerinin değişmesinde etkili olmuştur. Kimi zaman erkeğin hegemonyası altında başkaldırmaya ve kendi isteklerini dile getirmeye çalışan Yılmaz'ın filmindeki kadınlar ne melektir ne de şeytan. Dolayısıyla bu filmlerle beraber sinemamıza yeni ve özgür bir kadın modeli doğmuştur (Dorsay, 2000a, 215). $\mathrm{Bu}$ filmlerde kadın cinselliği erkeğin arzusuyla betimlenmemekte, var oluşun doğası 
gereği sunulmaktadır. Sinemada kadının kimliğinin yeniden konumlandığı döneme ışık tutan filmlerden bazıları, Atıf Yılmaz'ın Bir Yudum Sevgi, Şerif Gören'in Firar, Zeki Ökten'in Pehlivan, Yavuz Turgul'un Fahriye Abla, Bilge Olgaç'ın Kaşık Düşmanı gibi yapımlarıdır (Dorsay, 2000a, 213). Ancak bu dönemdeki filmlerde kadın özgürlügü ve kadının bireyselleşmesi yalnızca cinsellik ve kadınlık üzerine sınırlandırıldığından sinemadaki değișen kadın karakterleri sığ bir konumda kalmıștır.

Kaplan'a göre 90’lı yıllarda ise özel olarak kadın filmlerinden söz etmek mümkün değildir. $\mathrm{Bu}$ dönemde pop şarkıcısı ya da manken olan medyatik kadınlar beyaz perdede oyuncu olarak karşımıza çıkmıştır. Çekilen filmlerde kadınların mutsuzlukları maddi yetersizliklerden kaynaklanmaktadır. Her Şey Çok Güzel Olacak, Aşk Ölümden Soğuktur ve Asansör gibi filmler konuya ilişkin örnek verilebilecek yapımlardandır $(2003,162)$. 80’li yıllarda sinemada değişmeye başlayan kadın temsilleri olan başkaldıran, talepkâr, bastırılmış duygularını dışa vuran ve yine az sayıda da olsa, gelenek ve töreler karşısında çaresiz kadınlar 90’lı yıllarda da karşımıza çıkmıştır. Ancak bu filmlerde özellikle tutku, gizemlilik, iletişimsizlik, mutsuzluk, tatminsizlik yaşayan kadınlar öne çıkmaktadır (Künüçen, 2001, 61). Bu filmlerde kadının sürekli evde temsil edilmesinden ziyade, kadınlar kamusal hayatta ve erkeklerle iş hayatında rekabet halinde betimlenmiştir. Böylece zamanla toplumsal cinsiyet kodları değișerek, kadının ev ve çocuklarla ilgilenmesi gerekliliği, yerini zamanla erkeğe bırakmış, erkek de bu görevlerin bir parçası olmuştur. Ancak bu durum erkekler üzerinde başka bir buhran oluşturmuş, 1990'lı yılların ikinci yarısından itibaren çekilen filmlerde kadının sebep olduğu, mahvolan ve mağdur erkek hayatları filmlere konu olmuştur. (Oktan, 2009, 193). Zeki Demirkubuz'un 90’lı yıllarda çektiği filmlerde de söz konusu mağdur erkeklerin, kadınlar sebebiyle cehenneme dönen hayatları işlenmiștir.

\section{Zeki Demirkubuz Filmlerinde Kadın Karakterler}

Zeki Demirkubuz bağımsız filmler yapan bir yönetmendir. Filmlerini ticari kaygı gütmeden yapan Demirkubuz, popüler sinemadan uzak, izleyiciyi kendisiyle yüzleştiren ve hayatın keşmekeşini, kadın erkek ilişkilerinin çıkmazlarını sorgulayan ve tartışan bir sinema anlayışını benimsemiștir. Filmlerinde yarattığı karakterler; hayata tutunamamış, zaaflarının kurbanı olan, melankolik, içinde bulundukları durumlara kimi zaman karşı çıkan ve acı çeken kişilerdir.

Ancak Demirkubuz'un filmlerindeki kadın erkek karakterleri arasındaki ilişkide çok keskin ayrımların bulunduğu düşünülmektedir. Bu filmlerde kadınlar erkekleri tehdit eden, erkeklerin hayatında büyük yıkımlara sebep olan varlıklardır. Demirkubuz'un bir erkek gözüyle yarattığı kadın karakterlerin, erkeğin bakış açısını yansıttığı ve ideolojik bir yaklaşımla oluşturulduğu fikri feminist çevrelerce kabul görmektedir. Buna göre yönetmenin filmlerinde kadınların varlığının cinsellik ve kadınlık üzerine kurgulandığı ve bu kadınların erkek fantezisini temsil ettiği tartışılmaktadır. Filmlerindeki karakterleri gerçekçi ve hayatın içinden, yenilmiş, tutunamamış bir tasvirle sunan Demirkubuz, bu yönüyle kadını da alışılagelmişin dışında, farklı bir noktada konumlandırmaktadır. Onun filmlerindeki kadınlar cinselliklerini özgürce yaşayan, hayatlarını sorgulayan, mutsuzluklarına başkaldıran, utanmadan ne istediklerini ifade eden ve dominant kişilerdir. Bununla birlikte bu kadınlar istediklerini cinsellikle ve kadınlıklarını kullanarak yaptıran kadınlardır. Bu noktada kadın özgürlüğünü salt cinsellikle bağdaştıran bu filmlerin, erkek bakış açısının bir ürünü olduğu görülmektedir. Öte yandan söz konusu filmlerde kadın 
ve erkek arasında öylesine keskin bir ayrım vardır ki, erkek her daim kadınların kurbanı olmuştur ve bu noktada izleyici "iyi" olanın yani erkeğin yanına çekmeye çalışılmaktadır. Dorsay'ın belirttiği gibi bu filmlerdeki karakterler, kolay sınıflara girmeyen, kendi özgür soluklarını alan, kimi zaman sevilesi, kimi zaman da nefret edilesi yaratıklardır (2004b, 209). Ancak burada nefret edilesi karakterler kadınlardır. İzleyicinin gözünde erkek karakter, zavallı ve başına gelenleri hak etmemiş gibi algılanarak konumlandırılır.

Konuyu daha ayrıntılı ifade etmek için bu makalede incelenecek olan üç film haricinde yönetmenin diğer filmlerindeki kadın karakterlere kısaca değinmek faydalı olacaktır.

2001 yılında çekilen Yazgı, Albert Camus'nun Yabancı romanından esinlenerek yapılmış bir filmdir. Filmin erkek karakteri Musa, yaşama karşı kayıtsız, depresif ve donuk mizaçlı biridir.

Yaşadığı hayata öylesine yabancıdır ki, annesinin ölümüne bile kayıtsız kalır. Film Musa'nın iş arkadaşı olan Sinem, Musa'nın patronu Naim ve Musa'nın arkadaşı Necati arasında yaşanan olaylarla gelişir. Bu filmde kadın karakter, evli patronuyla ilișkisi olan ve kocasını da aldatan biridir. Musa'nın bakışı sadece Sinem'in dekoltelerine odaklanır ve Sinem'i arzular. Filmde kadın, sadece cinsel bir objedir ve eril nazarla var olmaktadır. Filmde kadının sadece bir arzu nesnesi olarak ihanetin sahibi olduğu düşünülmektedir.

Aynı yıl çekilen İtiraf adlı filmde ise yine kocasını aldatan bir kadın portresiyle karşılaşırız. Filmde kadın, Yazgı'da olduğu gibi ihanet eden ve bundan pişman olmayan, kendi istekleri için hayatındaki erkeğin onurunu düşünmeyen bir karakter olarak tasvir edilmiştir.

Demirkubuz'un 2003 yılında çektiği ve baş karakteri kendisinin canlandırdığı diğer filmi Bekleme Odası'dır. Bu filmde de kadın erkek ilişkileri arasındaki çıkmazları ve ihaneti görürüz. Önceki filmlerine göre bu filmde aldatan kadın karakteri baskın değildir ancak kadına karşı şiddetin sergilendiği ve kadınların erkek karaktere nazaran pasif bir şekilde tasvir edildiği görülmektedir. 2006 yılında çekilen Kader filmi ise Masumiyet filmindeki Bekir ve Uğur'un geçmiş hayatlarında yaşadıkları olayları, tanışmalarını ve Bekir'in Uğur'a olan takıntısını anlatmaktadır. Burada da Uğur'un annesi, kocasını aldatan bir karakter olarak karşımıza çıkmaktadır. Öte yandan filmde Bekir'in Uğur'a olan tutkusunun bir erkeğin hayatını nasıl çıkmaza sürüklediği görülmektedir. Yönetmenin sonraki yıllarda çektiği Kıskanmak (2009) ve Kor (2016) isimli filmlerinde de kocasına ihanet eden, hayatındaki zorluklardan çıkış noktası olarak kadınlığını kullanan kadın karakterler betimlenmektedir.

\section{Yöntem}

Bu makalede incelenecek filmler C Blok, Masumiyet ve Üçüncü Sayfa filmleridir. Çalışmada bu üç filmdeki kadın karakterlerin, toplumda hangi statüyle yer aldıkları, sosyo-kültürel konumları, erkeklerle olan ilişkileri incelenecek ve söz konusu filmlerde cinsiyetçi yaklaşımların ve kadın rollerinin nasıl betimlendiği metin analizi yöntemiyle incelenecektir. Bu noktada metin analizi yöntemine değinmek faydalı olacaktır. Alan McKee, kendisinden anlam çıkarılan her şeyi bir metin olarak ifade eder (McKee, 2003, 4). Dolayısıyla herhangi bir nesne, sanat eseri veya bir obje metin olarak yorumlanabilmektedir. Bununla beraber metnin bir yapı olduğu ve bu yapıda sadece metnin yapısal örgüsü değil, onu çevreleyen dış gerçeklik de 
metne dahil edilerek, bu diş gerçeklikle metni analiz etmek gerekmektedir (İnceoğlu ve Çomak, 2009, 19). Bu anlamda herhangi bir resim, film, radyo programı veya televizyon haberinin yapısını metin olarak kabul ettiğimizde bu metni oluşturan veya oluşumuna katkı sunan diş gerçekliklerle birlikte metni incelemek gerekmektedir. Metin analizi ise medya metinlerini inceleme türlerinden sadece biridir (Erdoğan, 2012, 149). Bu anlamda metin analizinin, araștırmacıların, diğer kişilerin dünyayı nasıl algıladıkları ve anlamlandırdıkları hakkında bilgi toplamalarının bir yolu ve bir veri toplama süreci olduğunu belirtmek mümkündür (McKee, 2003, 1). Bu kapsamda metin analizi, kültürel araștırmalarda, medya çalışmalarında ve sosyal bilimlerin diğer alanlarında sıklıkla kullanılan bir yöntemdir.

Diğer bir tanımlamayla metin analizi, metin olarak belirlenen görsel ya da sözel ifadeleri yorumlama pratiğidir. Bu yöntem uygulanırken dikkat edilecek husus, metin olarak kabul edilen medya içeriğinde veya kültürel içerikte anlamlı ve önemli olanın karar verilip seçilmesidir. Ayrıca metnin oluşumuna kaynaklık eden, sosyal ve toplumsal anlam, metinden anlam çıkarabilmek ve metnin bağlamını değerlendirmek için önemli bir noktadır. Dolayısıyla metin analizi yapılırken metnin tarihsel, toplumsal veya sosyal bağlamlarına dikkat edilmelidir. Sosyal bilimler çerçevesinde metin analizinde aranan, genellikle metindeki yüklenmiş anlamın sosyal, toplumsal anlamı ve sonuçlarıdır (Erdoğan, 2012, 149).

Metin analizi, medya içeriklerinin söylem biçimlerini, ideolojik konumlarını, anlatı stratejilerini, imaj yapımını ve etkilerini analiz etmek için kullanılmaktadır (Kellner, $2014,6)$. Bir metindeki şiddet olaylarının sayısını belirleyen kantitatif içerik analizinden, örneğin, kadınların, siyahların veya diğer grupların görüntülerini inceleyen nitel çalışmalara kadar, medya içerikleri üzerindeki çalışmalar da metin eleştirisi kapsamındadır. Bu yöntem ile aynı zamanda, metinlerin anlamını açmak veya metinlerin anlam üretme şeklini açıklamak için çeşitli eleştirel teoriler uygulanmaktadır. 1960'lı yıllardan itibaren, edebi-formalist metinsel analiz, sadece yazılı dillerde değil, aynı zamanda filmlerin ve televizyon içeriklerinin görsel ve işitsel dilleri gibi diğer sözel olmayan kodlarda da anlam yaratılmasının araştırıldığı bir sistem olan göstergebilimden türetilen yöntemlerle geliştirilmiştir (Kellner, 2014, 6).

Metin analizinde, metinden anlam çıkarmak için en önemli şey bağlamdır. Metni incelerken üç seviyeli bağlama bakılabilir (Erdoğan, 2012, 152):

Metnin tümü (geri kalanı): Bunun anlamı, örneğin, bir olay tarihsel bağlamı içinde ele alınmalıdır. Çünkü aynı şey/olay/karakter aynı zamanlarda farklı anlamlandırılabilir, bir zamanlar kötü olarak nitelenirken, başka bir zamanda, kurban veya yanlış anlaşılmış olarak nitelenebilir.

Metnin türü/genre: Metni anlamlandırmada metinsel bir tür oldukça önemlidir: Bir türde gülünç olan bir eylem, bir diğer türde hakaret veya suç olarak nitelenebilir.

Metnin dolaşımda olduğu geniş kamusal bağlam: Bir metnin önemi ve anlamı aynı zamanda geniş toplumsal yapıdaki anlamla bağıntılıdır.

Çalışma kapsamına alınan filmler aşağıdaki sorularla bağlantılı olarak incelenecek ve bu soruların cevaplarına ulaşılmaya çalışılacaktır. 
- Feminist film teorisine göre sinemadaki kadın temsilleri nasıldır ve nasıl olmalıdır?

- Üç filmdeki kadın karakterlerin farklılıkları ve ortak noktaları nelerdir?

- Feminist film teorisine göre bu üç filmdeki kadınlar nasıl temsil edilmektedir?

\section{Bulgular}

\section{Blok (1994)}

C Blok, Zeki Demirkubuz'un ilk filmidir. Filmde evlilik kavramı ve kadın erkek iliş̧ileri sorgulanırken, kent hayatının simgelerinden olan apartmanlardaki kalabalık yalnızlıklara ve iletişimsizliklere de dikkat çekilmektedir. Film Tülay, Selim, Halet ve Aslı adındaki karakterler üzerinden ilerlemektedir. Büyük bir sitede C Blok'ta yaşayan Tülay ve eşi Selim'in mutsuz bir evliliği vardır. Tülay vaktini dışarıda gezerek, annesini ziyaret ederek geçirir. Aslı ise Tülay'ın evine temizlik için gelen hizmetçidir. Tülay’ın hayatı, Aslı ile apartman görevlisinin oğlu Halet'i kendi evinde, kendi yatağında birlikte olurken görmesi ile değişecektir. Bu tesadüfle Tülay, hayatındaki gerçekle yüzleşecek ve tatminsizliğini keşfedecektir.

Filmin ilk sahnesinde C Blok'un önündeki arabada Tülay'ın evden çıkmasını bekleyen Halet görülmektedir. Tülay'ın apartmandan çıkmasıyla Halet, kendisini Tülay'ın evinde bekleyen Aslı ile buluşur. Bundan sonra olaylar gelişir. Tülay evliliğindeki tatminsizliği Halit ve dışarıdaki erkeklerle gidermeye çalışacak, Aslı ise Selim'in tecavüzüne uğrayacaktır.

Tülay ve Aslı farklı sosyal statüye sahip kadınlardır. Tülay, monoton evliliğinden bunalmış ve kendini sürekli evin dışına atan bir kadındır. Maddi durumu yerindedir. Ancak manevi tatminsizlik çekmekte ve eşi Selim ile arasındaki mesafe giderek artmaktadır. Demirkubuz filmlerinin simgelerinden olan televizyonun karşısında susarak evliliklerini geçiren Tülay ve Selim çıkmazdadır. Tülay sürekli sıkıldığını dile getirmekte ve bunu arkadaşı Fatoş ile paylaşmaktadır.

Tülay, hizmetçisi Aslı gibi özgür olmak ve tutkulu bir ilişki yaşamak istemektedir. Aslında Tülay, evinde karşılaştığı o tesadüften sonra uyarılmış ve "uyandırılmış", tahrik olmuştur. Burada uyandırılmak tabiri hem cinsel anlamda hem de ruhen ne istediğini görme anlamındadır. Bu karşılaşma Tülay için bir ayna niteliği taşımaktadır. Burada feminist film teorisyenlerinin vurgusunu yaptıkları kadın modeli karşımıza çıkar. Tülay, alışılagelmiş ev hanımı, mazbut kadın rolünün karşısında durur. Kendi isteklerinin ve tutkularının peşinde olan, sınıf atlamak için yaptığı evliliğin boyunduruğu altına girmeyen, kendi hayatını sorgulayan bir kadındır. Bu bağlamda $C$ Blok'da Türk sinemasındaki dört dörtlük kadın rolünün bariyeri yıkılmaktadır. Zira klasik sinemada her kadının anlatısal ve görsel perspektiften bakıldığında hepsinin de erkekler nezdindeki işlevi dışında var olma haklarının olmadığını hissettiği ve bu yüzden kendi kimliklerini oluşturamadığı açıkça görülür. (Smelik, 2008, 112). Demirkubuz'un yarattığı Tülay karakteri, zengin bir kocaya sahip, evine temizlikçi gelen ve hiçbir sorumluluğu olmayan, maddi açıdan rahat yaşayan özgür bir kadındır. Arabasına atlayıp her gün kendini dışarıya atmaktadır. Ancak bu özgürlük değildir onun için zira evliliğini bir pranga olarak görmektedir. Genellikle 1980 öncesi dönemde Türk sinemasında arzularının peşinde koşan kadın ve kendi istediğini yaptıktan sonra pişman olan kadın, toplum baskısı içinde sıkışıp kalan kadın modelleri karşımıza çıkmıştır. Bu anlamda kadınlar Simone de Beauvoir'nin açıkladığı konumdadırlar: 
İşte kadının vaziyetini belirgin biçimde ayırt edici kılan aslında bütün insan türü gibi hür ve bağımsız olsa da, kendilerini erkeklerce Öteki konumunu kabullenmek zorunda bırakıldıkları bir dünyada bulmalarıdır... Kadının dramı da -benliğini daima elzem addeden her öznenin (ego) en temel istekleri ve lüzumsuz sayıldığı bir vaziyetin zorlamaları arasındaki bu çelişkide yatmaktadır $(1993,29)$.

Filmde diyaloglara fazla yer verilmemiştir. Tülay, sessizliğiyle içindeki çığlığı duyurmaya çalışmaktadır âdeta. Zeki Demirkubuz burada, kadınların üzerindeki toplumsal ve erkek egemen baskıyı sessizlik metaforunu kullanarak temsil etmektedir. Kadının sessizliği bir tehlike işaretidir. Filme göre saf ve kendi halinde olan Halit'i kışkırtan ve ona âdeta kendi "malıymış" gibi sahip olan, onunla istediği şekilde sevişen bu iki kadındır. Kadını hep evin içinde konumlandıran Yeşilçam filmlerinin aksine C Blok'un kadınları dışarıda, ev hayatının dışında temsil edilmektedirler. Buraya kadar filmin klasik kadın temsillerini ve tabu sayılan konuları yıktığını belirtmek mümkündür. Ancak Tülay’ın tüm gün sokaklarda başıboş bir şekilde gezmesi, annesi ondan yardım istediğinde onu azarlaması, bencil ve arayıșta olması, yine kadını cinsellik temelinde konumlandıran bir karakter olarak izleyiciye sunulmaktadır. Zira Aslı, Selim tarafından tecavüze uğradığında, Tülay da Halit ile birlikte olmaktadır. Burada toplumsal statüleri farklı iki kadının yine cinsellik etrafında konumlandırıldığı görülmektedir. Bu açıdan $C$ Blok filmindeki iki kadın karakter, feminist film teorisinin karşı durduğu, klasik kadın imajından farklı bir boyutta temsil edilmektedir. Ancak bir kadının mutsuzluğunu ya da bunalımını, dış dünyadan kaçma isteğini, içindeki boşlukları cinsellikle ve farklı erkeklerle birlikte olma arzusuyla doldurmak istemesi yine eril nazar etkisinde gerçekleşen bir temsiliyeti ifade etmektedir. Evine ve evliliğine dair hiçbir aidiyet hissetmeyen Tülay'ın tüm mutsuzluğunu ve sıkıntısını cinsellik üzerinden gidermeye çalışması, sahilde ona dokunan erkeklere karşı müdahale etmeyişi de kadını ve kadınlığı basite indirgemektedir. Filmde Tülay, (evlendikten sonra kocası sayesinde) üst sinıfın temsil ettiği bir kadınken, Aslı alt sınıfın temsil ettiği ancak daha özgür bir kadın olarak karşımıza çıkmaktadır. Burada özgürlüğün de sorgulanması gerekmektedir. Bir kadının özgürlüğü sadece cinselliği istediği șekilde istediği kişiyle yaşayabilmesi midir? Bununla beraber filme dair diğer feminist eleștiri, her iki kadının da izleyicide "yoldan çıkaran", "müsait kadın" izlenimi yaratmasıdır.

Tülay ve Aslı'nın birbirlerinden farklı karakterler olsa da ortak noktaları, her ikisinin de erkeklerin gözünde bir cinsel bir nesne olmasıdır. Tülay, sahildeki erkekler tarafından bir fantezi unsuru olarak algılanır, Aslı da Halet'in cinsel fantezilerinin ortağıdır. Ancak burada her iki kadının da bu durumlara "gönüllü" olduğu, erkeğin sebepsiz bir halde böyle davranmayacağı ve erkeği kışkırtanın kadın olduğu anlayışı izleyiciye aktarılır. Tülay sahilde yanına gelen ve kendisini taciz eden erkeklere karşı kayıtsızdır hatta onları kendisine dokunmalarına teşvik etmektedir. Aslı ise temizliğe gittiği evi kendi eviymiş gibi öylesine benimser ki, Tülay’ın kıyafetlerini giyerek Halet ile Tülay ve Selim'in yatağında birlikte olur. Aslı, öylesine rahat bir kadındır ki, Tülay'ın eși Selim ile beraber geç saatlere kadar televizyon izlemektedir. Bu durumda zaten eșiyle sorunlar yaşayan ve eşinin ilgisizliğinden bunalan Selim evde Tülay'dan daha çok vakit geçiren Aslı'ya tecavüz eder. Bir kadının yıkımına neden olan yine bir kadındır. Tülay, Selim'in Aslı'ya tecavüz etmesinin sorumlusu olarak aktarılır. Tülay sebebiyle Aslı tecavüze uğramıș, Selim bunalıma girmiș ve Halet akıl hastanesine yatmıştır. Erkeğin trajedisinin nedeni kadındır. Öte yandan filmde, bir kadının hikâyesi anlatılıyor gibi görünse de, kadın üzerinden erkeğin dramı kutsallaştırılır. 
Ana karakter kadın olsa da, sözde bir ana karakterdir. $C$ Blok, şehirli-modern bir kadın karakterin yalnızlığını ve içindeki boşluğu, sıkıntıyı anlatmak isterken aslında yan karakter olan Halet'in trajedisini anlatır (Öztürk, 2006b, 90).

\section{Masumiyet (1997)}

Zeki Demirkubuz'un en beğenilen filmleri arasında gösterilen Masumiyet, hapisten yeni çıkmış, saf bir kişilik olan Yusuf'un, hayat kadını Uğur ve Uğur'a aşık olan Bekir ile yollarının kesişmesi üzerine şekillenmektedir. Yusuf, ablasının yakın arkadaşıyla kocasını aldatması üzerine arkadaşını öldürmüş ve ablasını da yaralamıştır. Bu sebeple hapse giren ve hapisteki cezasını dolduran Yusuf ilk olarak ablasının evine gider, eniştesiyle buluşur. Ancak eniştesi aldatılmanın öfkesini hâlâ yaşamakta ve olaydan sonra dilini kaybeden Yusuf'un ablasına şiddet uygulamaktadır. Bunun üzerine Yusuf, pansiyona gider ve orada Bekir ve Uğur ile tanışır. Uğur'un Çilem adında bir kızı vardır. Kız, pansiyondaki salonda sürekli televizyon izlemektedir. Sonradan kızın, anne karnındayken Uğur'un yediği dayaklardan dolayı sağır ve dilsiz olduğu anlaşılır. Bekir ise umutsuz bir şekilde Uğur'a aşıktır ancak Uğur'un başka erkeklerle birlikte olmasını kendisine yedirememektedir. Bekir, Yusuf ile dertleşir ve yıllardır çaresizce Uğur'un peşinden gittiğini anlatır. Burada Uğur'un, Bekir'in bașına gelen tüm felaketlerin tek sebebi olduğu algısı oluşmaktadır.

Filmin sonlarına doğru Bekir, Uğur ile tartışır ve intihar eder. Bekir'in yerini ise Yusuf alır. Yusuf da Uğur'a aşık olur ancak aşkı Bekir gibi karşılıksızdır. Uğur'un gözü öylesine dönmüştür ki, Zagor Orhan'ın hapisten çıktığını duyunca kızı Çilem’i de bırakıp kaçar. Yusuf, Uğur'u bulmak için kendisine bırakılan adrese, Ankara'ya gider. Ancak mafya Zagor ile Uğur'un peşine düşmüştür. Yusuf, Uğur'un kızıyla bir başına kalmış, Uğur ile Zagor ise öldürülmüștür.

Masumiyet'te $C$ Blok'ta olduğu gibi bir kadın üzerinden kutsiyet atfedilen erkeğin trajedisine odaklanılır. Hikâyenin odak noktasında Yusuf vardır, filmdeki özne erkektir. Dolayısıyla filmin söylemi de erkek egemen bir söylemdir. Filme hâkim olan cinsiyetçi dil, ataerkil söylemin en somut örneğidir. Filmde edilen küfürler așırı bir yoğunlukla tekrar edilmektedir (Güler, 2008, 35).

Filmde sürekli açık olan televizyondan Yeşilçam filmlerinin replikleri duyulmaktadır. Bu replikler ile Uğur ve Bekir arasındaki diyaloglarda da cinsiyetçi söylem hâkimdir. Yusuf'un ablasının ve Uğur'un kızı Çilem'in dilsiz oluşu, kadının sesini duyuramaması ve kadın üzerindeki baskının sessizlik metaforuyla temsil edilmesi anlamına gelmektedir. Çilem'in sessiz ve dilsiz dünyasında çocukluğa atfedilen masumiyet ve vicdan görülmektedir. Duymasa da, televizyon küçük kızın tek dünyasıdır. Çilem, annesinin öldüğünü televizyondan görür. Bekir ve Yusuf'un Uğur'a duyduğu aşk ile küçük kızın televizyona duyduğu aşk, kahramanları aynı sonuca götürmektedir. Televizyon ve aşk bağlantısının, "en çok sevdiğimiz şey, canımızı en çok acıtan şeydir." mesajını taşıdığını belirtmek mümkündür.

Feminist film teorisine göre Uğur karakteri, sinemadaki klasik kadın temsillerinden farklı bir konumdadır. Ataerkil düzenin karşısındadır, başına buyruktur ve fahişelik yaparak hayatını sürdürmektedir. Fahișeliği herhangi bir erkeğin zoruyla değil kendi isteğiyle yapmaktadır. Bununla beraber Uğur, küfürlü konuşur ve sert bir mizacı vardır. Yaşadığı tüm zorluklara rağmen kararlılıkla büyük aşkı Zagor Orhan'ın peşinden gitmektedir. Yeşilçam'ın klasik iffetli kadın tiplemesinden aykırı 
bir konumdadır Uğur. Ancak feminist film teorisine göre burada bir çelişki vardır; Uğur patriyarkal düzenin karşısında konumlanırken, önce Bekir'i sonra Yusuf'u yönetmekte, yönlendirmekte, pasif ama etken bir kadın portresi çizmektedir. "Erkek gibi" tabirine uygun bir karakterde olan Uğur, kendisine aşık olan erkekleri peşinde sürükleyerek hayatına dahil eder ancak kendisi sadece Zagor Orhan'a aittir. Uğur kimseyi zorlamamıştır, Bekir de Yusuf da kendi istekleriyle onun yanındadırlar. Uğur, ataerkilliğe boyun eğmeyen bir kadındır ancak erkek hegemonyasına karşıyken, "erkekleşmiş" bir karakterdir. Fahişeliği kendi isteğiyle yapması, Uğur karakterini bir kadının olması gerektiği gibi özgürleștirmemiș, aksine yine erkek düşüncesinin bir dışa vurumu olarak sınırlandırmıştır. Bir kadının ayakta kalmak için fahişelik yapması, kadını güçlü göstermekten ziyade, kadının sadece bedeni ile varlı̆̆ını sürdürebilmesine indirgemektedir. Filmde Uğur, bedenini erkeklere sunarak, bir sömürü nesnesi haline gelerek ayakta kalmaktadır.

Bununla beraber Yusuf'un dilsiz ablasına kocasının uyguladığı şiddetin sebebi aldatmadır. Böylece kadın hem dilsiz kalarak hem de kocasından şiddet görerek patriyarkal düzenin hegemonyası altında cezalandırılmaktadır. Çilem'in ve Yusuf'un kız kardeşinin dilsizliğinin sebebi erkeklerdir. Yusuf'un kız kardeși, eșini aldatmasının bedelini dilsiz kalarak, Uğur da yanlış tercihlerinin bedelini kızının sağır ve dilsiz olmasıyla ödemiş̦tir. Her iki kadının da yaptıklarının cezasını erkekler vermiștir. Yusuf'un hapse girmesine sebep olan olay, evli olduğu halde başka bir erkekle kaçan ablasını ağzından vurmuş olmasıdır. Kadının başına buyruk davranışı ataerkil şiddetle cezalandırılmıştır. Yusuf ve Bekir, kendi istekleriyle Uğur'un yanındadırlar. Uğur, kendisine takıntı derecesinde bağlanmış olan Yusuf ve Bekir'e hiç karşıllk vermez ve onlara herhangi bir talepte bulunmaz. Ancak burada $C$ Blok'ta olduğu gibi erkekleri yönlendiren, onların hayatını çıkmaza sürükleyen bir kadın temsili olarak Uğur karakteri karşımıza çıkmaktadır.

Filmdeki karakterler duygularını uçlarda yaşayan kişilerdir. Bekir, Uğur'a tutkuyla bağlıyken, Uğur da Zagor Orhan'a tutkuyla bağlıdır ve adeta tüm hayatını onun için yaşamaktadır. Bu duygu sonunda Yusuf'a da bulaşır ve o da Bekir gibi Uğur'a kapılıp gider. Uğur'un ihtirasları bulaşıcıdır ve hayatındaki erkekler bu aşırılıklar sarmalı içerisinde kendi sonlarını hazırlamaktadırlar. Filmde kadın erkek dünyasındaki farklılıklar; sessizlik, şiddet, cinsellik, acizlik gibi uç kavramlarla betimlenmektedir. Ayrıca Uğur, fedakâr ve anaç bir anne değildir. Çocuğuyla neredeyse hiç ilgilenmemektedir. Burada Türk sinemasındaki klasik kadın tasvirlerinin karşısında konumlanan Uğur karakteri, yine uç bir özellikle temsil edilmektedir. Daha önce de belirtildiği gibi Türk sinemasında kadının iki zıt şekilde, ya melek ya da şeytan kadın karakterleriyle tasvir edildiği düşünülmektedir. Buna göre beyaz perdede kadın ya fedakâr, anaç biri ya da bencil, anne olsa bile çocuğuyla ilgilenmeyen bir karakter olarak izleyiciye sunulmuştur. Uğur da bu iki zıt betimlemeden bencil ve ilgisiz anne sıfatına sahip bir karakterdir.

\section{Üçüncü Sayfa (1999)}

Üçüncü Sayfa, filmlerde figüranlık yaparak geçinmeye çalışan İsa ile evli ve iki çocuğuyla yaşayan komşusu Meryem arasındaki ilişkiyi konu edinmektedir. İsa, çalıştığı yerden çalınan 50 dolardan dolayı kendisinden şüphelenilerek ölümle tehdit edilmektedir. İsa intihar etmeye karar verir ancak ev sahibi kapıya dayanır ve İsa'dan birikmiş kirayı ister. Sabrı tükenmiş olan İsa, tüm isyanını ev sahibinden çıkarır ve onu silahla vurur. Daha sonra bayılır. Bir süre sonra uyanır ve polisler tarafından 
karakola götürülür. Daha sonra eve dönen İsa'ya komşusu Meryem yardım eder ve ona yemek getirir. İlerleyen günlerde İsa'nın peşine düșen adamlar İsa'nın evine gelir ve 50 doları ondan ister. İsa'nın yardımına yine Meryem koşar ve adamlara parayı Meryem verir. Bir akşam Meryem'in kocası eve gelir, Meryem'e şiddet uygular ve tecavüz eder. Sesleri duyan İsa olaya müdahale etmek ister ancak korkar, bir şey yapamaz. Daha sonra Meryem İsa'dan kocasını öldürmesini ister. Bu arada Meryem, İsa'ya ev sahibini öldürdükten sonra ona yardım ettiğini, delilleri ortadan kaldırdığını, ev sahibiyle ilişkisi olduğunu, kocasının buna göz yumduğunu itiraf eder. İsa, Meryem'in kocasını öldürmeyi kabul eder ancak başaramaz, Meryem'in kocası bir tartışmada bıçaklanarak öldürülür. Daha sonra İsa figüranlık için il dışına gider. Geri döndüğünde Meryem'in dairesini boş halde görür. Öte yandan ev sahibinin oğlu, İsa'ya evden çıkması gerektiğini, evi akrabalarına verdiğini söyler. Daha sonra İsa minibüsteyken, Meryem'i lüks kıyafetler içinde bir apartmanın önünde görür. Meryem'i bulur ve evine gider. Silahı Meryem'e doğrultur. Ancak tetiği çekemez. Meryem, vuracaksan vur der ve ev sahibinin oğluyla da ilișkisi olduğunu, İsa'yı kullandığını itiraf eder. İsa evden ayrılır ve kapının önünde kendini silahla vurur, sahne kararır.

Feminist film teorisine göre yorumlandığında Üçüncü Sayfa, Demirkubuz'un diğer filmlerinde olduğu gibi kadın egemenliğinde ilerlemekte ve erkeği edilgen olarak konumlandırmaktadır. Masumiyet filmindeki Uğur gibi, Meryem de cesaretli, ihtiraslı ve baskın bir karakterdir. 0 da Uğur gibi kadınlığını kullanarak insanları yönlendirmektedir. Ancak Uğur'un sınıf atlama kaygısı yoktur. Meryem ise sinıf atlama kaygısıyla önce kocasını aldatır sonra da kocasını aldattığı kişi olan ev sahibini, o adamın oğluyla aldatır. Üstelik Meryem'in hayatındaki erkekler bu ihaneti bilirler ancak buna göz yumarlar. $\mathrm{Bu}$ zincirleme ihanet şebekesinin son kurbanı ise kendi halinde saf bir genç olan İsa olur. İsa, Meryem'in ona yaptığı yardıma ve gösterdiği ilgiye kayıtsız kalamaz. Meryem, ilk başlarda saf ve ezilen Anadolu kadını izlenimi verse de daha sonra onun farklı planları olduğu anlaşılır. İsa ise Meryem'in yanında pasif bir karakterdir. Öylesine ezik ve korkaktır ki, evine gelip ondan para isteyen adamlara bile sesini çıkaramaz. Burada Zeki Demirkubuz, sinemanın klasik kurtarıcı, güçlü erkek karakterine sert bir vurgu yaparak kadını, yani Meryem'i "kurtarıcı-güçlü" bir karakter olarak yansıtmaktadır. Meryem, İsa'yı adamlardan kurtarıp büyük bir cesaretle adamlara sözleriyle tepki vererek İsa'dan istedikleri parayı onlara ödemektedir. Meryem yönlendirilen, ezilen, etki altına alınan bir kadından ziyade, yönlendiren, yöneten, etki altına alan bir kadın olarak tasvir edilmektedir. Ancak Meryem, feminist film teorisinin paradigmalarıyla örtüşmemektedir. Bu filmde de kadın, bir tehlike unsuru olarak sunulmuştur. Kadınlığını kullanarak istediklerine ulaşan, kendinden başka kimseyi umursamayan kadın tasviri diğer filmlerde olduğu gibi burada da izleyiciye sunulmaktadır. Üçüncü Sayfa'da yönetmenin diğer filmlerinde olduğu gibi erkek karakterin trajedisi kadın üzerinden aktarılmakta ve erkeğin acısı kutsallaştırılmaktadır. Meryem de Uğur gibi kadınlığını kullanarak hayatını devam ettirmektedir. Filmde her iki kadın karakterin de varlığı cinsellikle kısıtlanmakta, kadın sadece kadınlığını kullanarak ve erkekleri kurban ederek varoluşunu devam ettirmektedir anlayıșı işlenmektedir. Filmdeki erkek karakter İsa fedakârdır, mazlumdur ve iradesizdir. Meryem ise kötü şeylere sebep olur, yönlendirir ve yönetir. Öte yandan Meryem'in çocuklarının ismi Sibel ve Can'dır. İsa'nın, “Sibel Can'ı hani sevmiyordun?” sorusu üzerine Meryem, "Kocam sevince koymak zorunda kaldım.” der. Burada kadının üzerindeki ataerkil baskıyı 
görmek mümkündür. Kadının, kendi çocuklarına isim koymaya bile hakkı yoktur. Kocanın bir ismi sevmesi, çocuklara o ismi koymak için yeterlidir. Evde hâkimiyet sahibi olan erkeğin iktidarının boyutu, kadını dövmekten, çocuklarına isim koymaya kadar uzanır. Burada filmlerde kadınların en kötü halde, evlenene kadar babasının malı, evlendikten sonra da kocasının malı olduğu anlayışı görülmektedir (Butler, 2011, 91). Meryem de kocasının malıdır. Ancak bu durumdan kurtulmanın yolunu üç erkeği, İsa'yı, ev sahibini ve ev sahibinin oğlunu kullanmakla bulur.

\section{Sonuç ve Değerlendirme}

Feminist film teorisinin karşı çıktığı üzere her üç kadının da hayatlarının ortak noktası kadınlıklarını bir araç olarak kullanmalarıdır. Bu kadınlar cinsel bir obje olarak sunulmakta ve bu filmlerde kadınlar cinsellikle bağdaștırılmaktadır. Meryem'in ve Uğur'un hayatlarında cinsellik bir çıkış noktası ve bir araçtır. Tülay ise cinselliği hayatındaki tatminsizliğin çözümü olarak görür. Her üç filmdeki kadın karakterler erkekleri baştan çıkaran kadınlardır. Masumiyet filmindeki Uğur'un, ona zaafları olan erkekleri baştan çıkarma gibi bir derdi yoktur. 0 sadece fahişelik yapmaktadır. Ancak baștan çıkaran kadın, fahişe ile kesişir. Her ikisi de kahramanın hayatını allak bullak edebilecek, güçlü, kendinden emin kadın figürüdür. Sıklıkla soğuk ve açık bir biçimde duygusuz olan baștan çıkaran kadın, erkeğin cinsel nesnesidir (Butler, 2011, 90).

Zeki Demirkubuz'un bu çalışmada esas alınan üç filmindeki erkek ve kadın karakterler, pek çok açıdan birbirleriyle benzeşmektedir. Bu filmlerdeki edilgen kişilikler olan Yusuf, Halet, İsa gibi erkekler korkak, aciz ve pasif karakterli kişilerdir ve onları kadınlar yönlendirmektedir. Tülay varlıklı bir erkekle evlenerek sınıf atlamış bir kadındır. Üçüncü Sayfa'daki Meryem de Tülay gibi sınıf atlamak için bir erkeği kullanmıștır. Masumiyet filmindeki Bekir, Uğur'a, Üçüncü Sayfa'daki İsa ise Meryem'e silah çekmektedir. Ama sonunda iki erkek de kendisini vurmaktadır. Uğur da baskın ve cesur bir kadındır Meryem de. Tülay pasif agresif bir kişiliktir ancak yine de kendi istekleri doğrultusunda yaşamak isteyen bir kadın olarak karşımıza çıkmaktadır. Söz konusu filmlerin kilit noktası kadınlardır, kadınlar hikâyeye yön vermektedir. Ancak bu filmlerde kadınlar yoluyla erkeğin trajedisi anlatılmaktadır. $\mathrm{Bu}$ açılardan bakıldığında Demirkubuz'un üç filminde de kadınlar, feminist film teorisinin paradigmalarıyla çelişmektedirler. Burada, erkek bir yönetmenin elinden çıkmış ve erkek ideolojisiyle oluşmuş, "her şeyin sorumlusu kadındır" fikri üzerine temellenmiş filmler karşımıza çıkmaktadır. Zira genel algı olarak sanat filmleri kadını daha çok ön plana çıkarır, kadını özgürleştirmeye ve bireyselleştirmeye çalışır ancak yine de bu filmler geleneksel filmlerle örtüşecek biçimde nicelikli, estetik ve kapalı ideolojik egemenlik temelinde şekillenmektedir (Öztürk, 2009c, 19). Erkek yönetmenin ve senaristin kadınlara dair tüm düşünceleri, filmlerinde mutlaka kendini belli edecek bir nokta bulmaktadır.

Zeki Demirkubuz'un söz konusu üç filmi de eril nazar etkisinde şekillenmiştir. Bununla beraber Yeşilçam'daki kadın temsilleri genel olarak edilgen, güçsüz, mağdur ve sürekli ev ve aile hayatına hapsolmuş karakterler iken, Demirkubuz'un üç filminde de kadınların ev dışında, daha özgür, daha güçlü ve daha etken oldukları görülmektedir. Ancak bu durum, söz konusu filmlerdeki hikâyelerin kadının cinsel işlevi etrafında dönmesini engelleyememektedir. 
Sonuç olarak çalışmada yapılan analizler ışığında, her üç filmdeki kadın ve erkek karakterlerin ihtiraslarını, sevgilerini veya nefretlerini uçlarda yaşadığı ve kadınların sadece bedenleriyle cinsel bir meta olarak tasvir edildiği görülmüştür. Bu filmlerde kadınlar sadece cinsellikleriyle temsil edilirken, erkekler trajik hayatlarında kadınların mağdur ettiği bir çeşit kurban olarak konumlandırılmaktadır. Filmlerdeki erkek karakterler, kadınlar tarafından acizleştirilen veya acizleşen kişilerdir. Ayrıca çalışmada söz konusu filmlerdeki kadın karakterlerin cinsellik ve ihanet noktasında birleştiği ve bu karakterlerin erkek bakışının bir uzantısı olarak eril nazar etkisinde temsil edildiği görülmüștür. Bu filmlerde kadın karakterleri sürekli olarak "aldatmaya meyilli", "ihtirasları için her şeyi yapabilecek bir varlık", "her erkeğin hayatını bir kadın mahveder" gibi algılarla oluşturan Demirkubuz, Kocaeli Üniversitesi'nde düzenlenen bir etkinlikte aldatmayan kadından hikâye olmadığını söylemiştir (Demirkubuz, 2016). Ancak bu görüş, kadını ve kadın hikâyelerini sığ bir noktada değerlendiren bir görüşün ifadesidir. Kadını ancak ihanetle nitelendiren bu anlayış, feminist çevrelerin tepkisini çekmektedir. Bu anlamda aldatmayan erkekten hikâye oluyorsa, aldatmayan kadından da çok daha nitelikli hikâyelerin çıktığını ve çlkabileceğini belirtmek mümkündür.

\section{Kaynakça}

\section{Kitaplar}

Butler, A. (2011). Film Çalışmaları. (A. Toprak, Çev.), İstanbul: Kalkedon.

Butler, J. (2008). Cinsiyet Belası, Feminizm ve Kimliğin Altüst Edilmesi. (B. Ertür, Çev.), İstanbul: Metis.

De Beauvoir, S. (1993). Kadın "İkinci Cins": Genç Kızlık Çağı. (B.Onaran, Çev.), İstanbul: Payel.

Donovan, J. (1997). Feminist Teori. (A. Bora, M. A. Gevrek, F. Sayllan, Çev.), İstanbul: İletişim.

Dorsay, A. (2000). Sinema ve Kadın. İstanbul: Remzi.

Dorsay, A. (2004). Sinemamızda Çöküs ve Rönesans Yılları. İstanbul: Remzi.

Durakbaşa, A. (2002). Halide Edip Türk Modernleşmesi ve Feminizm. İstanbul: İletişim.

Erdoğan, İ. (2012). Pozitivist Metodoloji ve Ötesi. Ankara: Erk Yayınları.

Esen, Ș. (1996). 80'ler Türkiye'sinde Sinema. Eskișehir: Etam.

Felsefe Logos Dergi, (2001). Feminist Felsefe. (15), İstanbul: Bulut.

İnceoğlu, Y. Çomak, N. (2009). Metin Çözümlemeleri. İstanbul: Ayrıntı.

Kaplan, N.F. (2003). Toplumsal Konumu ve Bu Konumunun Değişimiyle Türk Sinemasında Kadın. İstanbul Ticaret Üniversitesi Fen Bilimleri Dergisi, 2 (4), 149-173).

Künüçen, H. (2001). Türk Sinemasında Kadının Sunumu Üzerine. Kurgu Anadolu Üniversitesi İletişim Bilimleri Fakültesi İletişim Dergisi, (18), (s.51-64).

McKee, A. (2003). Textual Analysis: A Beginner's Guide. London: Sage.

Oktan, A. (2009). Türk Sinemasında Hegemonik Erkeklikten Erkeklik Krizine: YazlTura ve Erkeklik Bunalımı Sınırları. Erkek Kimliğinin Değişe(meye)n Halleri. (H. Kuruoğlu, Der.), İstanbul: Beta. 
Özden, Z. (2004). Film Eleștirisi: Film Eleștirisinde Temel Yaklaşımlar ve Tür Filmi Eleștirisi. Ankara: İmge.

Öztürk, S. R. (2000). Sinemada Kadın Olmak: Sanat Filmlerinde Kadın Imgeleri. İstanbul: Alan.

Öztürk, S. R. (2006). Zeki Demirkubuz Sinemasi, Biyografya 6, (s.75-100), İstanbul: Bağlam.

Öztürk, S. R. (2009). Sinemanın Dişil Yüzü: Türkiye'de Kadın Yönetmenler. İstanbul: Om.

Ryan, M. \& Kelner, D. (2010). Politik Kamera. (E. Özsayar, Çev.), İstanbul: Ayrıntı.

Smelik, A.(2008). Feminist Sinema ve Film Teorisi. (D. Koç, Çev.), İstanbul: Agora.

Yücel Ş. (2011). 80’lerden Günümüze Sinemada Kadın Temsilleri, Sinemada Kadın. (M. Taşkaya, E. U. İlbuğa, Haz.), (42-68), Antalya: 48. Uluslararası Antalya Altın Portakal Film Festivali Yayını.

\section{Tezler - Makaleler}

Arslantepe, M. (2010). Sinemada Feminist Teori. http://akademikpersonel.kocaeli. edu.tr/marslantepe/bildiri/marslantepe18.10.2010_20.37.45bildiri.pdf. (Erişim Tarihi: 10.01.2019).

Güler, N. (2008). Zeki Demirkubuz Sinemasında Kadın Temsilleri. Yüksek Lisans Tezi, Ankara Üniversitesi, Ankara.

İnceoğlu İ. (2015), Beyaz Perdede Kadın Anlatısı: Mavi Dalga Filminin Feminist Incelemesi. http://cins.ankara.edu.tr/14_7.pdf (Erişim Tarihi: 05.01.2019).

Kellner, D. (2014).CulturalStudies, Multiculturalism, and Media Culture. https://pages. gseis.ucla.edu/faculty/kellner/essays/culturalstudiesmulticulturalism.pdf (Erişim Tarihi: 19.04.2019).

Uluç, G. Soydan, M. ve Ankaralıgil, N. (2006). Medyada Kadının Temsiline İlişkin Feminist Bir Okuma Çalışması: TEMPO Dergisi, II. Uluslararası Kadın Araştırmaları Konferansı, Doğu Akdeniz Üniversitesi Kadın Araştırmaları ve Eğitim Merkezi, Gazi Mağusa - KKTC, 26-28.04.2006.

\section{İnternet Siteleri}

Zeki Demirkubuz Söyleşisi, Kocaeli Üniversitesi. http://www.hurriyet.com.tr/zekidemirkubuz-aldatmayan-kadindan-hikaye-olmuyor-40064230 (Erişim Tarihi: 05.01.2019). 
